\title{
Controles Concentrado e Difuso no Direito Constitucional: A Eficácia Temporal das Decisões ${ }^{\prime}$
}

José Paulo Sepúlveda Pertence ${ }^{2}$

O conceito mesmo de Constituição e de sua supremacia na ordem jurídica, as noções conseqüentes de inconstitucionalidade formal, na inobservância do processo legislativo constitucional, e material, por violação das normas constitucionais, isso na linguagem de Kelsen, antecipam ou vedam o conteúdo de leis futuras.

O grande Mauro Cappelletti em sua pequena obra-prima, Controle judicial da constitucionalidade das leis no direito comparado, notava que, ao lado da internacionalização dos valores constitucionais e da tentativa de sua concretização pelo controle judicial, nota-se um grande e fascinante movimento de aproximação entre os dois sistemas, o americano e o austríaco, nas origens radicalmente contrapostos. Uma atenuação portanto das nítidas contraposiçōes iniciais. E como as próprias ideologias estão na base daquela ou de outras contraposições, vão sempre mais se atenuando, quando não até mesmo se unificando e se harmonizando.

A evolução do tema "o controle de constitucionalidade no direito constitucional brasileiro" é um dos exemplos mais expressivos dessa tendência de harmonização dos dois sistemas puros, inicialmente contrapostos e aparentemente inconciliáveis do controle de constitucionalidade de leis e atos normativos.

A evoluçāo do tema no Brasil não se fez, como se fez em muitos sistemas, a partir dos inicialmente contrapostos - o americano e o austríaco - por mera aproximação ou concessões de um sistema a outro, mas na verdadeira construção de uma simbiose institucional ambiciosa, audaciosa, de convivência dos dois sistemas.

Palestra proferida no âmbito do Programa de Pós-Graduação da FGVDIREITO - RIO, sem revisão pelo Autor.

2 Ministro do Supremo Tribunal Federal. 
A Constituição escrita, ainda quando flexível, é sempre um ensaio de fixação de valores fundamentais da organização do Estado e suas relaçōes com a sociedade. É do voto historicamente fundador do tema de John Marshall que, com certeza, todos os que têm formulado constituiçōes escritas sempre o fizeram com o intuito de assentar a lei fundamental e suprema da nação.

Da idéia de lei suprema vem necessariamente a idéia de inconstitucionalidade das normas inferiores, seja por inobservância do processo legislativo constitucional, seja por violação das normas substanciais da Constituição. E essa idéia de inconstitucionalidade, uma idéia lógica de inconstitucionalidade, reforça-se, como se sabe, com o mecanismo da rigidez constitucional, da imposição de um processo mais complexo, mais demorado, de elaboração de emendas à Constituição do que da elaboração de leis ordinárias, embora a inconstitucionalidade não seja exclusiva das constituições rígidas. Ao menos a inconstitucionalidade formal é fenômeno que se manifesta também nos regimes de Constituição flexível, conforme o conceito de Constituição em sentido material que Kelsen reduzia exatamente à fixação do órgão competente para legislar e do processo pelo qual o poderia fazer. Tudo o mais nāo é logicamente necessário na Constituição. De qualquer sorte, a Constituição escrita flexível é hoje, com a exceção tradicional da Inglaterra e, em termos, de Israel, um conceito puramente teórico. Mas, mesmo na Constituição rígida, o controle de constitucionalidade é conseqüência possível, mas não necessária. O exemplo mais claro e mais importante é, sem dúvida, o da França, que sempre teve, desde a Revolução, constituições formalmente rígidas. No entanto, sem jamais conceber que o controle de constitucionalidade pudesse ser uma competência judicial.

Orlando Bittar, notável professor paraense, autor ainda hoje, passado mais de meio século, de um dos melhores livros sobre controle de constitucionalidade que já se publicou nesse país, é que nota que na verdade o que resulta na França, como na Inglaterra, é que, no mundo da realidade, é a lei que é superior à Constituição, e não o contrário, dada a inexistência de um órgão independente do órgão legislativo, capaz de fazer essa fiscalização da constitucionalidade.

Assim, Constituição escrita, Constituição rígida e as conseqüentes noções de inconstitucionalidade são momentos iniciais da racionalizaçāo moderna dessa ânsia permanente dos homens, que tem sido própria de todos os tempos, diz ainda Cappelletti, de criar ou descobrir uma hierarquia entre as leis e de garanti-la.

É claro que nisso tudo, nessa tentativa de criação permanente de leis fundamentais, de leis insuscetíveis de revogação por outras leis ordinárias, há, é claro, uma positivação, uma tentativa de positivação da idéia de direito natural, que cresce com o conteúdo das constituiçōes modernas, não mais reduzidas, ao modo que o definia a Declaração dos Direitos do Homem e do Cidadão da Revolução Francesa, à separação dos poderes e à garantia dos direitos fundamentais. Mas, desde a Constituição mexicana de 1917 e a Constituição de Weimar da Alemanha de 1919, toda Constituição moderna, em maior ou menor extensão, contém sempre um projeto de sociedade futura, a lei de organização de poderes e garantia de direitos. 
O grande problema está no terceiro momento, o da garantia da supremacia das normas constitucionais. É, disse Cappelletti, a tentativa de transformar a imprecisão e a imóvel estaticidade daquelas fórmulas e a inefetividade daquela prevalência em uma efetiva e dinâmica e permanente concretização, através da obra de um intérprete qualificado.

O problema está, primeiro, na identificação, na consagração, na eleição desse intérprete qualificado da Constituição, com um imenso poder político que daí advém, celebrizado na frase de um Chief Justice americano, Charles Hughes: "vivemos sobre uma Constituição, mas a Constituição é o que a Suprema Corte diz o que ela é". Segundo, de ordenar o processo de controle por este intérprete qualificado da constitucionalidade dos atos inferiores. E aí o direito comparado permite decantar das experiências concretas, desses dois séculos e meio de constitucionalismo, três tipos puros de solução para o controle da constitucionalidade: o primeiro, de feitio marcadamente francês, é o do controle político. Sua fundamentação ideológica é o respeito ortodoxo à doutrina da separação e independência dos poderes, que se afirma incompatível com a idéia de indagação judicial sobre a validade e, via de conseqüência, sobre a força obrigatória da lei. É de Zagrebelsky a observação de que o controle não é apenas uma limitação à supremacia do Parlamento, mas também um desvio do princípio democrático representativo. E com essa base ideológica é que se mantém, há mais de dois séculos, a resistência francesa a qualquer idéia de controle judicial.

O controle de constitucionalidade na França (e nos poucos países que ainda lhe seguem o modelo) ou tem sido entregue ao próprio Parlamento ou a um órgão parcial dele, o Sénat Conservateurs, o Sénat ou o Comité Constitutionnel. Na Quinta República, o atual Conselho Constitucional da Constituição Gaullista de 1958 é, embora mais forte que os seus predecessores, ainda um típico órgão político de controle, não apenas por sua composição - ex-Presidente da República e 9 membros, sendo 3 nomeados pelo Presidente, 3 pela Assembléia e 3 pelo Senado -, mas, sobretudo, pelo método do controle exclusivamente preventivo, inserido no próprio processo legislativo. Aprovado um projeto de lei pelo Parlamento francês, tem-se, facultativamente, a submissão daquele projeto ao Conselho Constitucional, que dirá da sua constitucionalidade, e, se positiva, faz devolver o projeto à Assembléia para que delibere manter a lei ou proceder à reforma constitucional necessária à sua validade. Em algumas leis, isso é obrigatório. As chamadas leis orgânicas são obrigatoriamente submetidas a essa decisão prévia de validade, preventiva de constitucionalidade, do Conselho Constitucional. Esse sistema francês de controle político, seja pela própria Assembléia, seja por estes órgãos dela derivados, já dominou a Europa continental. Hoje, além da França, nos últimos tempos o seu campo de preponderância foi o dos Estados socialistas, com exceção da (ex)-Iugoslávia.

Fiel à sua inspiração nitidamente francesa, a nossa Constituição do Império adotou não apenas o controle parlamentar da constitucionalidade, mas também da interpretação das leis. Lia-se no artigo 15: “é da atribuição da Assembléia Geral 
fazer leis, interpretá-las, suspendê-las e revogá-las, e velar na guarda da Constituição". No título do poder judicial, não havia nada de que fosse possível extrair, sequer um poder implícito, de indagar da validade das leis.

A Constituição do Império tinha uma disposição singular no seu artigo 178 , que é a única positivação da velha idéia de Constituição em sentido material e de Constituição em sentido formal dando-lhe conseqüências jurídicas. Desse dispositivo se preceituava que é só constitucional o que diz respeito à organização dos Poderes e aos direitos civis e políticos, aí protegidos formalmente por uma extrema rigidez: uma lei prévia autorizando para que a próxima legislatura se ocupasse de reforma neste ou naquele sentido e depois uma aprovação, se não me engano, por $2 / 3$ de votos. Tudo o mais, embora contido na Constituição imperial, poderia ser emendado, poderia ser reformado ou revogado por lei ordinária.

A prática da Constituição imperial é um exemplo expressivo da inefetividade deste controle judicial parlamentar. Basta notar que, apesar desta distinção do artigo 178, entre a Constituição rígida, que era apenas, à moda do artigo 16 da declaração, apenas o que dissesse respeito à organização dos poderes e aos direitos fundamentais, no entanto, a inefetividade desse controle parlamentar e dessa rigidez se mostra na história política do Império. Salvo o Ato Adicional de 1834, que realmente é uma reforma e profunda na Constituição, na primitiva Constituição de 1824 - e este por si se fez sob a forma de emenda constitucional -, todas as leis de grande relevância política e atinentes à organização dos poderes e aos direitos fundamentais se fizeram por lei ordinária. Assim, o próprio recuo do ato adicional para a Lei de Interpretação de 1840 , que volta mais centralizadora que a Constituição primitiva.

A criação do Conselho de Estado, a criação do cargo de Presidente do Conselho de Ministros, figura principal abaixo do Imperador do governo imperial e a profunda reforma eleitoral da Lei Saraiva, tudo isso se fez por lei ordinária, tal a ineficácia da idéia de controle político.

No Brasil desse sistema político nada nos resta senão o que se insere no próprio Poder Legislativo, em que o juízo prévio da constitucionalidade do projeto toca, primeiro, ao Congresso e, segundo, ao Presidente da República mediante o mecanismo do veto, que tem na alegação de inconstitucionalidade do projeto um dos seus motivos. No entanto, insusceptível de qualquer verificação jurisdicional e, por conseqüência, absolutamente inócuo.

Além do veto, o mecanismo mais eficaz de controle político no Brasil é indireto e sua legitimidade está ligada à existência do controle jurisdicional. É a recusa, sobretudo pelo Poder Executivo, de dar execução à lei que entenda inconstitucional, invertendo a iniciativa e deixando ao interessado que vá discutir em juízo se existe ou não a inconstitucionalidade alegada como motivo da recusa de executar a lei. Mas há uma velha discussão sobre a validade desse mecanismo. Ao tempo do puro controle difuso era predominante, era praticamente sem discrepância, o juízo de validade desta recusa pelo Poder Executivo de executar uma lei que ti- 
vesse inconstitucionalidade. Mas, com a introdução da representação geral a que chegaremos, de 1965, e muito mais com a atual ação direta de inconstitucionalidade, que amplia significativamente o rol dos legitimados à provocação do controle direto, ganha cada vez mais relevo a oposição daqueles que negam ao Executivo essa recusa, dado que tem ele, na ação direta, uma via presumidamente rápida de provocar o controle de constitucionalidade, inclusive com essa singularidade do sistema brasileiro, que é uma generosíssima aplicação do poder de suspensão cautelar das leis pelo Supremo Tribunal no início do processo da ação direta.

O segundo sistema puro, já o diz, é o controle difuso incidente de constitucionalidade, não previsto explicitamente pela Constituição americana, embora tivesse precedentes nas colônias que se conglomeraram para formação do Estado Federal americano. No campo da Constituição federal, sabidamente, trata-se de uma construção jurisprudencial da Suprema Corte dos Estados Unidos, a partir da célebre decisão do caso Marbury vs. Madison ${ }^{3}$ do Chief Justice John Marshall, em 1803.

A lógica do raciocínio de Marshall que sustenta esse acórdão histórico de nosso tema ainda seduz pela sua clareza e simplicidade e se traduziu, até com mais racionalidade, por Ruy Barbosa, nos primórdios da vivência da Constituição da República. Em síntese, para julgar um caso é preciso interpretar, o que pressupõe a escolha da norma aplicável. Ora, pode dar-se o chamado conflito de normas à primeira vista aplicáveis ao mesmo caso. Se este conflito se dá entre normas da mesma hierarquia, são conhecidos os processos de superação dessa antinomia. A partir do critério cronológico, a lei posterior revoga a lei anterior. E, pelo processo de especialidade, a lei especial não é revogada pela lei geral superveniente extra. Mas este conflito pode dar-se entre normas de hierarquia diversa. Então, há de prevalecer a de grau mais alto. Por sua própria natureza e sentido, já aludimos, a própria Constituição pretende sempre ser a suprema lei do país e por isso há de prevalecer sempre sobre a lei ordinária. Daí que, diz Marshall, para cumprir o seu dever de aplicar a Constituição como lei suprema é dever do juiz, inerente à sua função jurisdicional, afastar a lei ordinária que se contraponha à Constituição. Ou, na síntese perfeita de Ruy Barbosa, entre um ato legislativo ilegítimo de nascença e a Constituição, cuja legitimidade nenhuma lei pode contestar, entre o ato nulo da legislatura e a Constituição, o juiz, para executar a segunda, a lei fundamental, nega execução ao primeiro, à lei inconstitucional. Mas é fundamental, na lógica do sistema difuso, a compreensão dessa declaração de inconstitucionalidade como uma decisão incidente, o que os processualistas de hoje chamariam como a solução de uma simples questão prejudicial necessária à solução da causa. O juiz, na verdade, não anula a lei, não revoga a lei inconstitucional, mas, no caso concreto, deixa de aplicá-la para aplicar a Constituição.

Por isso, a operação, na lógica de Marshall, compreende-se inteiramente na função jurisdicional, porque é necessária à soluçāo do caso concreto, onde haja conflito entre a Lei Suprema e uma lei de grau inferior, e, por isso, não representa 
afronta ao dogma da independência dos poderes. Mas, para que assim seja, como é próprio da decisão judicial, a que declara a inconstitucionalidade da lei incidentemente para a solução de uma causa há de ter sua eficácia limitada à causa em que incidentemente se resolveu a questão e às partes do processo.

É nesta relatividade da eficácia objetiva e subjetiva da declaração de inconstitucionalidade, que é a pedra de toque de sua compreensão lógica no âmbito da função jurisdicional, que está o ponto frágil do sistema difuso sempre que se pretendeu transplantá-lo do sistema de alicerces da common law e do direito anglosaxão para ordenamentos como o nosso, dos chamados civil law, de tradição romanista típica. Permitido o controle a qualquer juiz - como é da lógica do sistema difuso -, mas limitada à causa a eficácia da decisão, resulta obviamente que a mesma lei pode ser afastada, por inconstitucional, da regência de numerosas causas, enquanto permaneça regendo numerosas outras, em que a questão constitucional não se pôs ou foi repelida.

Nos Estados Unidos, essa fragilidade teórica do controle difuso é, na verdade, teórica, dado o princípio stare decisis, que é estrutural do sistema jurídico anglo-saxão. Vale dizer, da força obrigatória dos precedentes, particularmente dos precedentes da Suprema Corte, de tal modo que, embora - a expressāo é de um jurista americano - continue nos repertórios, a lei declarada inconstitucional pela Suprema Corte, até eventual virada jurisprudencial da Corte, é uma lei morta.

De outro lado, está no seu próprio nome; sendo inerente à função jurisdicional, o controle incidente de constitucionalidade das leis é logicamente difuso. Parte da jurisdição, ele toca todo e qualquer juiz, independentemente de sua hierarquia. É esse o sistema que, racionalizado pelo gênio de Ruy Barbosa, o Brasil transplanta com a República e a Federação do Direito americano. O sistema resultava claro, na Constituição, na previsão de que, das sentenças da Justiça dos Estados, caberia recursos para o Supremo Tribunal, se se questionou a validade de leis federais e a decisão lhe negou validade ou aplicação, ou se contestava leis ou atos dos governos locais em face da Constituição e a decisão estadual dava a validade, a aplicabilidade, dessa lei ou ato estadual.

Esse sistema difuso, em tese, vigora até hoje integralmente no país. Em qualquer causa e perante qualquer juiz ou tribunal, a questão prejudicial de inconstitucionalidade pode constituir fundamento da ação ou da defesa, ou mesmo ser posta de ofício pelo juiz. Declarada incidentemente, a inconstitucionalidade limita-se a explicar, a fundamentar, a inaplicação ao caso da lei. O princípio, que segue em vigor, salvo na área do controle concentrado, é a inadmissibilidade total de constituir a declaração de inconstitucionalidade ou a anulação da lei inconstitucional o próprio objeto da demanda.

Somando-se à resistência histórica de origem francesa, esta ausência do stare decisis no sistema romanístico do continente europeu pode explicar que, embora se rendendo progressivamente à idéia de um sistema judicial de controle, a Europa, com a teimosa exceção francesa, age inclinada pela criação da outra modalidade, 
do que chamaríamos o outro sistema puro de controle judicial de constitucionalidade. É o sistema concentrado por via principal - a inconstitucionalidade aí é o próprio objeto do processo - e com eficácia universal do que foi decidido, com eficácia erga omnes. A criação é de um dos maiores teóricos de Direito do século XX, Hans Kelsen, quando elabora a Constituição austríaca, de 1920. O modelo chega a expandir-se na (ex)-Tchecoslováquia e Espanha ainda no primeiro pós-guerra e, após a Segunda Guerra Mundial, tem uma expansão por quase toda a Europa e em vários países da América Latina.

No Brasil, a Constituição que se segue à Revolução de 1930 encontra posto o dilema entre o sistema difuso, que se instituíra com a primeira Constituição republicana em 1891, e o sistema concentrado das novas constituições européias. E surgem aí na Constituição, na efêmera Constituição de 1934 - que durou até 1937 -, os primeiros passos na tendência reforçada pela evolução constitucional subseqüente, para um sistema misto, para um acoplamento dos dois sistemas puros, o americano e o austríaco de controle judicial de constitucionalidade.

São em três vertentes que se manifestam claramente na Constituição de 1934 as primeiras influências do sistema europeu. A primeira se introduziu no tema, que os abusos da Primeira República tornavam politicamente delicadíssimo, da intervenção federal nos Estados. A primeira Constituição republicana admitia a intervenção federal nos Estados para coibir a inobservância dos princípios constitucionais da União, que não definia. Só com a reforma de 1926 é que se enumeram esses, que a doutrina depois viria a chamar de "princípios sensíveis à Constituição", mas deixando a juízo do Congresso a sua existência.

É a Constituição de 1934 que se aproveita da modalidade do sistema europeu, então novo, de controle concentrado, para criar a que depois viria a ser chamada "representação interventiva". Na Constituição de 1934 o próprio ato por violação dos princípios constitucionais da União seria previamente submetido ao Supremo Tribunal, para que o declarasse válido ou não, o que reflexamente conduzia ao controle da constitucionalidade da lei ou ato local que constituísse o fundamento, o motivo alegado, para a intervenção federal.

Manteve-se, porém, como regra geral, com essa única exceção, o sistema do controle difuso de 1891, que em todos os textos constitucionais republicanos fica explícito na enumeração das hipóteses constitucionais do recurso extraordinário, que, embora difuso, o sistema reserva ao Supremo Tribunal pelo mecanismo do recurso extraordinário o poder de dar a última palavra, ou, como dizia o saudoso ministro Aliomar Baleeiro, "essa triste responsabilidade de errar por último".

Deram-se ainda na Constituição de 1934, primeiro contra a possível instabilidade da jurisprudência constitucional, o surgimento do que viria a ser chamado "reserva de plenário", a regra de que só pela maioria absoluta dos seus membros poderia um tribunal declarar a inconstitucionalidade de lei, e uma resposta a esta, brasileira, sem antecedentes conhecidos, a questão da relatividade dos efeitos da declaração de inconstitucionalidade no sistema difuso. Previa-se no artigo 91 da 
Constituição de 1934: "compete ao Senado Federal, suspender a execução no todo ou em parte, de qualquer lei ou ato, deliberação ou regulamento, quando hajam sido declarados inconstitucionais pelo Poder Judiciário". A inovação subsiste e está hoje no artigo 52, X, da Constituição de 88: "compete ao Senado Federal suspender a execução, no todo ou em parte, de lei declarada inconstitucional por decisão definitiva do Supremo Tribunal Federal".

O mecanismo, é claro, visou a conciliar a natureza jurisdicional e, pois, de eficácia relativa à causa e às partes da declaração incidente de inconstitucionalidade com a possibilidade de sua extensão por ato político do Senado.

A Constituição de 1946, em nosso sistema, inova pouco sobre a de 1934. Mantém-se com a disciplina do Recurso Extraordinário o sistema difuso, com a possibilidade de extensão erga omnes da decisão incidente por ato do Senado.

O controle direto segue vinculado à intervenção federal. Muda apenas o momento desse controle da constitucionalidade da intervenção federal. Ao invés de se controlar a constitucionalidade da intervenção já decretada, passa, de 1946 em adiante, o Supremo Tribunal a controlar a constitucionalidade, a ofensa ou não, pelo ato local ou pela lei e ato local, dos princípios fundamentais da Constituição Federal. E a extensão desses princípios sensíveis fez com que isso se transformasse num embrião de controle direto, principal, abstrato de constitucionalidade de leis, mas apenas de leis ou atos estaduais, porque funcionalmente vinculado ao processo de intervenção federal.

O grande passo no que eu chamei de processo gradual de acoplamento dos dois sistemas puros vem, assim como quem não quer nada, com uma reforma judiciária de 1965, ainda sob a vigência da Constituição de 1946. Entre outras, deu-se ao Supremo Tribunal a competência para julgar a representação por inconstitucionalidade de lei ou ato normativo federal ou estadual encaminhada pelo Procurador Geral da República. Dera-se, aí, o grande passo para o acoplamento, com a clara introdução, sem prejuízo da subsistência do controle difuso, do método de controle concentrado e por via direta e principal, já aí não apenas das leis estaduais, mas também de leis federais, o que lhe dava, obviamente, outro relevo político.

A nova representação era, assim, de total amplitude, o que foi permitido por sua desvinculação do processo político de intervenção da primitiva representação interventiva. Assim, a extensão do objeto do controle passava a compreender leis e atos normativos federais e a extensão a toda e qualquer forma de inconstitucionalidade, e já não apenas aquela que se reduzia na representação interventiva aos princípios sensíveis da Constituição.

Era uma clara ruptura, assim, com o sistema de controle difuso incidente da Constituição americana. Não se tratava mais de sistema difuso, mas de um sistema concentrado no Supremo Tribunal. Já não se tratava de uma questão prejudicial de uma declaração incidente de inconstitucionalidade, mas a argüição de inconstitucionalidade era o objeto do próprio processo; e a eficácia, erga omnes, a eficácia 
universal da declaração, clara filiação ao sistema europeu, iniciado na Áustria e ampliado no segundo pós-guerra, primeiro na Itália e na Alemanha; posteriormente na Espanha, Portugal, Grécia e, hoje, na Europa Continental e em vários países latino-americanos, dos quais me recordo a Colômbia, Peru e a Bolívia.

Três pontos marcam-lhe a diversidade em relação ao sistema europeu. A inexistência de uma corte constitucional, até porque, mantido integralmente o controle difuso, era preciso um ponto de confluência e este só poderia ser o Supremo Tribunal, órgão de cúpula do sistema difuso e órgão exclusivo do controle concentrado. A coexistência com o sistema difuso, que, na amplitude com que se estabeleceu no Brasil, pelo menos naquele momento, não conhecia precedentes. No sistema europeu básico, o que havia não era o sistema difuso, era o poder de um juiz da causa, reconhecendo a relevância da questão de inconstitucionalidade suscitada, suspender o processo e remeter à Corte Constitucional a decisão exclusivamente sobre a argüição de inconstitucionalidade. E o que marcou esta representação geral de inconstitucionalidade, surgida em final de 1965, é a legitimação exclusiva de um órgão, o Procurador Geral da República, que foi o ponto da polêmica, da prática desta representação, até a Constituição de 1988.

Quando a representação se destinava apenas a preencher um pressuposto da intervenção federal nos Estados, a legitimaçāo do Procurador Geral era compreensível, ele era o representante judicial da União que postulava perante o Supremo o reconhecimento da constitucionalidade da intervenção no sistema primitivo de 1934, e depois da inconstitucionalidade do ato estadual que legitimaria a intervenção federal. É claro, no entanto, que esta exclusividade do Procurador Geral, somada ao autoritarismo do regime daquela época, levaria inevitavelmente à possibilidade dele de servir de instrumento de qualquer laivo, de qualquer tentativa de resistência da oposição.

O fato veio previsivel em 1971, quando, ante uma lei que autorizava o Ministro da Justiça a censurar livros, o partido de oposição, o MDB, representa ao Procurador Geral que, no entanto, se recusa a formular a representação. A ambigüidade do texto, que falava então em representatividade encaminhada pelo Procurador Geral, dava margem à tese que foi a do partido oposicionista, então, de que o procurador estaria vinculado a essa representação. Essa tese, no entanto, sempre foi repudiada pelo Supremo Tribunal e também neste caso, que ganhou tons de dramaticidade, quando um dos juízes da Corte, o Ministro Adaucto Lúcio Cardoso, que fora o voto vencido, revoltado, aposenta-se.

Desde então, porém, a cada arquivamento polêmico a discussão renasce, ora insistindo na interpretação da obrigatoriedade da propositura, ora de lege ferenda, postulando a ampliação da legitimação a outras personalidades ou entidades. Isso passa, o tema é retomado por Vitor Nunes na Conferência da Ordem em Curitiba. Posteriormente é retomada na chamada Emenda Leitão de Abreu, em 1984, uma tentativa de uma transição mais policiada, mas em que já se admitia que a representação pudesse ser proposta não só pelo Procurador Geral, ou pelo menos seria 
obrigatório o seu encaminhamento quando requerida pelos chefes dos poderes da União e dos Estados, ou pela OAB.

Este o panorama encontrado pela Assembléia Constituinte de 1987, que resultaria na vigente Constituição de 1988, que, no nosso tema, não afeta estruturalmente o sistema dúplice já estabelecido com a Emenda Constitucional de 1965. Mantém-se intocado o controle incidente e difuso de constitucionalidade que vinha da primeira Constituição republicana. Traz soluções de relevo com relação ao controle direto: o primeiro, de grande relevo teórico, mas de difíceis perspectivas de eficácia real, o controle da inconstitucionalidade por omissão, para a qual se previu uma ação direta de inconstitucionalidade por omissão e também o mandado de injunção para proteger direitos e prerrogativas cujo exercício estivesse inviabilizado por falta de lei necessária a dar eficácia à norma constitucional. Há no campo novos ares, o mandado de injunção. Já se formou maioria a respeito da regulação do direito de greve dos servidores públicos no sentido de abandonar aquela postura inicialmente tomada pelo Tribunal de uma decisão meramente declaratória da omissão, com comunicação ao Congresso para que a suprisse sem nenhuma sanção eficaz.

A segunda solução, aparentemente simples, para suprir a impossibilidade prática, funcional, de controle concentrado do Supremo Tribunal sobre a constitucionalidade de leis municipais, foi a previsão da $\mathrm{ADIn}^{4}$ estadual. Aparentemente simples, a solução já se revela fonte de problemas práticos e teóricos de complexidade.

A terceira é a de menor complexidade teórica, mas de longe a de maior relevo político: é a ampliação da legitimação ativa da ADIn, que deixa de ser monopólio do Procurador Geral e tem um dos plexos de legitimação mais amplos do mundo, diz o artigo. Se não se chega à ação popular como a Colômbia prevê há mais de um século, curiosamente sem prática, o certo é que dificilmente hoje uma questão de constitucionalidade minimamente séria deixa de encontrar um veículo para a propositura de uma açāo direta, que passa a ser facultada ao Presidente da República, à Mesa do Senado, à Mesa da Câmara, à Mesa das Assembléias Legislativas, aos Governadores dos Estados, ao Procurador Geral da República - já então liberto do dilema institucional que ele vivia quando acumulava as suas funções de chefe do Ministério Público, a exigir independência, e de Chefe da Advocacia da União, a reclamar, a exigir, integração e solidariedade com o governo - o Conselho Federal da Ordem dos advogados, o partido político com representação no Congresso e a confederação sindical ou entidade de classe de âmbito nacional.

O Procurador Geral, por isso, continua a ser o grande veículo da ação direta, marcada a sua atuação hoje, entretanto, com essa desvinculação da hierarquia do Poder Executivo. E é particularmente importante também a legitimação que se

Açāo Direta de Inconstitucionalidade. 
deu com a amplitude, também desconhecida em sua liberalidade, aos partidos políticos, aos quais basta ter um representante no Congresso Nacional para titularizar-se a provocação do controle concentrado.

Dizem, coisa que eu não acredito, que já houve até hipótese em que a declaração de legitimidade de determinada associação de classe levou-a a convencer um ilustre congressista a afiliar-se a um outro partido que não tinha nenhuma representação e, aí, a sua legitimação se ampliou. É que, com relação às associações de classe, uma longa discussão levou o Supremo, afinal - no que hoje vem a se chamar jurisprudência defensiva - a construir um requisito adicional para as confederações e entidades nacionais de classe, que é pouco compatível com a própria filosofia do controle concentrado, que se diz ser um processo objetivo que não visa à proteção de interesses, mas, senão, interesse na efetividade da Constituição. O Supremo acabou por limitar-se, sobretudo com relação às entidades de classe, impondo-lhes um requisito adicional de legitimação, que é a chamada "pertinência temática", a existência de um vínculo entre as finalidades institucionais da associação de classe e o tema da lei questionada.

O grande relevo político, além da atuação tradicional da Ordem e do Procurador Geral liberto, é efetivamente esse amplo acesso dos partidos - e, obviamente, com relevo dos partidos de oposição - ao controle concentrado.

Lembra-me que nos tempos tumultuosos do início do governo Collor, com plano econômico extremamente heterodoxo, eu via, cada vez que chegava para sessão plenária do Supremo Tribunal, um querido e saudoso amigo meu, ex-prefeito do Rio de Janeiro, Jamil Haddad. Eu sabia que o Jamil era médico e jogador da seleção de basquete e aí lhe perguntei: "Depois de velho você resolveu ser rábula?" "Não. É que o meu partido não tem bancada sequer para pedir verificação de quorum na Câmara. Então o nosso problema é o seguinte: deixa votar como quiserem e depois nós paramos o Supremo Tribunal na semana seguinte para discutir a nossa posição derrotada na Câmara."

Apenas para deixar o tema na pauta, eu lembraria o problema gerado no controle direto de constitucionalidade em torno das medidas provisórias, que, dada a sua eficácia imediata, superou a primitiva oposição do ministro Marco Aurélio ao cabimento da ação direta, porque vigorava como lei, embora com eficácia resolutiva. Mas, por outro lado, é verdade que, dada a vigência limitada no tempo da ação da medida provisória, antes que se rotinizassem as suas reduções, na verdade, a medida cautelar poderia tirar-lhe o que tinha de singular, que era a eficácia imediata de lei, deixá-la subsistir apenas como um projeto de lei do Executivo.

Anoto, quanto às leis municipais, a clara exclusão de seu controle pela Constituição Federal (a Constituição de 1988), abrindo a possibilidade da criação de inclusão na competência dos Tribunais de Justiça de uma representação de inconstitucionalidade, o que gerou intensa discussão no Tribunal e, às vezes, ainda leva a situações difíceis, dada a centralização imensa do nosso constitucionalismo, de tal modo que até um jovem jurista do Rio, que tem uma tese muito interessante, sus- 
tenta a absoluta inutilidade das Constituiçōes estaduais , na medida em que o que há de relevo realmente está na Constituição Federal e é de reprodução compulsória pelas Constituições estaduais, o que leva a uma difícil demarcação do âmbito da ação direta federal em relação à ação direta estadual, quando se alegue que a lei estadual ou municipal está violando a Constituição do Estado, que, no entanto, cujo preceito, cujo parâmetro de inconstitucionalidade argüido, é de reprodução compulsória. Eu cheguei a chamá-lo de norma absolutamente inócua, quando se deu a grande discussão a respeito: a norma da Constituição de São Paulo, que se punha como parâmetro numa questão sobre o IPTU, era norma que previa que compete ao Município instituir imposto sobre a propriedade territorial urbana. Isto, estivesse ou não na Constituição Estadual, continuaria com a mesma força, porque é característica do nosso federalismo essa outorga direta aos Municípios de um campo de competência tributária.

Eu queria uns poucos minutos sobre um capítulo extremamente fascinante da prática do sistema brasileiro de controle de constitucionalidade, que é o controle das emendas constitucionais.

A questão teórica da admissibilidade desse controle não oferece dificuldade maior. Diria mesmo que é um lugar comum na doutrina constitucional comparada a admissão de que, embora denominado poder constituinte derivado, o poder de reforma constitucional é um poder constituído e, portanto, não só a validade formal da emenda constitucional deriva da observância das regras constitucionais de competência e processo de elaboração das reformas constitucionais, como substancialmente depende do respeito às limitações materiais que a Constituição estabeleça, as famosas cláusulas pétreas. Curioso é que, embora a doutrina, comparada em termos quase universais, sustente a perfeita admissibilidade do controle de constitucionalidade das emendas constitucionais, se existem serāo raríssimos, no direito comparado, os exemplos de declaração de inconstitucionalidade de emenda constitucional. A Suprema Corte americana creio que se permitiu enfrentar duas vezes a questão: uma a propósito da famosa Lei Seca e outra a propósito do direito de voto das mulheres, e, em ambas, poupou-se de maiores indagações, entendendo que se tratava de political questions.

A rica jurisprudência do Tribunal Constitucional Alemão também enfrentou alguns casos de questionamento relevante de emendas constitucionais. Assim, a quebra do sigilo telefônico por autoridade administrativa, a entrada da República alemã na Comunidade Européia, a negativa de indenizaçāo quando da reunificação da Alemanha, negativa de indenização das expropriaçōes feitas pela República Democrática Alemã. Todos, no entanto, objeto de magníficas e sutis fundamentaçōes, como é dos juristas alemães, que se deliciam, como dizia Nelson Hungria, "em partir um fio de cabelo na vertical”, mas todas sem êxito.

No Brasil, contudo, a freqüência de açōes diretas contra emendas constitucionais, à qual, creio que nenhuma das múltiplas emendas escapou ilesa, tem correspondido a alguns julgamentos declaratórios de inconstitucionalidade de emendas 
constitucionais. Assim, são conhecidos os casos do primitivo IPMF, cuja inconstitucionalidade parcial se declarou não só no que submetia ao imposto os Estados e Municípios, por ofensa à imunidade tributária recíproca, que se considerou ponto fundamental do federalismo outras imunidades que funcionavam como proteção de liberdades fundamentais, a partir da liberdade religiosa, da liberdade de imprensa, e da anterioridade tributária, na qual confesso fiquei vencido e ainda estou inconformado. Dos sete impostos federais da União, três, pela Constituição originária, já se submetem a exceções à anterioridade, às vezes por decreto do Poder Executivo. É verdade que a anterioridade é filha, uma filha bastarda, residual, de um dos grandes dogmas do constitucionalismo tributário, que é a velha anualidade, a velha exigência de autorização orçamentária, que era o instrumento para dar eficácia à exigência de consentimento do Parlamento para o tributo. Como ela está reduzida hoje, como dizia o Ministro Francisco Rezek, parece algo de muita importância para a comodidade dos contadores, mas sem nenhum relevo político maior, na medida em que o princípio da não-surpresa e outras literaturas desse molde destrói-se inteiramente quando se sabe que tradicionalmente algumas das alterações tributárias mais relevantes das últimas décadas têm sido feitas em 31 de dezembro, se possível na edição extraordinária no Diário Oficial da União. Mas o certo é que então se declarou inconstitucional o primitivo IPMF nesses três aspectos.

Ao tempo em que a Suprema Corte americana se escafedia pela porta larga das political questions, no Supremo Tribunal brasileiro ingressava em 1926, quando da reforma Arthur Bernardes, a única emenda constitucional grande da Primeira República que foi questionada por habeas corpus e longamente examinada, embora não bote muito a mão no fogo quanto à decisão de mérito. Mas é impressionante como, em 1926, declarava-se com a maior tranquilidade a possibilidade do controle de emendas constitucionais.

A prorrogação da CPMF deu-se por uma inconstitucionalidade parcial, um defeito processual do curso bicameral das emendas. Na verdade, houve uma mudança substancial da Câmara sem o assentimento do Senado e, na emenda constitucional $\mathrm{n}^{\circ} 41$, a diferenciação, a declaração de inconstitucionalidade também parcial de uma diferenciação da base de cálculo da contribuição de inativos conforme tratar-se de funcionários dos Estados ou da União.

O brilhante teórico que é Oscar Vilhena Vieira anota, aliás, um paradoxo entre os textos constitucionais e a prática desse controle de emendas constitucionais na Alemanha e no Brasil. Na Alemanha, a cláusula pétrea é aparentemente mais sensível que a nossa, porque veda à emenda constitucional que afete o rol de direitos fundamentais. A nossa é textualmente mais rígida, ou menos rígida, porque reclama, para a inconstitucionalidade material da emenda, que ela tenda a abolir a federação, a república, a independência dos poderes e o que, como na Alemanha, dá uma amplitude imensa, os direitos e garantias individuais.

No entanto, com o texto que parece mais amplo, o constitucionalismo alemão não conhece uma só declaração de inconstitucionalidade, e nós, às vezes, com certo liberalismo, no dizer "o que tende a abolir direitos fundamentais", já 
caminhamos para meia dúzia de declarações. E, ademais, é a propósito das emendas constitucionais que surge a única modalidade no Brasil, por construção do Tribunal, de controle preventivo de constitucionalidade. Nos idos de, creio, 1977, dois senadores, Itamar Franco, que depois seria Presidente da República, e Mendes Canale impetram mandado de segurança ao Supremo Tribunal contra uma proposta de emenda constitucional que prorrogava os mandatos dos prefeitos. O relator original, Ministro Décio Miranda, na linha da jurisprudência ortodoxa, nega legitimação aos congressistas para, individualmente, contestar a constitucionalidade do que era então uma proposta de emenda constitucional. Parte de Moreira Alves a construção que propõe que diversamente do que ocorre com a inconstitucionalidade em geral, com relação às limitações materiais ao poder de emenda, a Constituição veda que sejam elas o objeto de deliberação. Em conseqüência, afirma a legitimação dos senadores, à base da construção de um direito, a não serem convocados a participar de uma deliberação que a Constituição proíbe, de uma matéria que a Constituição proíbe seja objeto de deliberação.

Finalmente, uma breve alusão a temas, ainda e cada vez mais efervescentes no Supremo Tribunal. Talvez o mais instigante deles seja o da eficácia temporal das decisões tomadas do controle de constitucionalidade.

A formação histórica do sistema brasileiro parte, como anotávamos, da adoção do sistema difuso americano, que, na sua própria lógica, quando possibilitava ao juiz da causa deixar de aplicar uma lei porque incidentemente a considerava inconstitucional, implicava a adoção do dogma, que já está no acórdão de Marshall, da nulidade da lei inconstitucional e, conseqüentemente, da eficácia retroativa (ex tunc) da declaração de inconstitucionalidade.

A proposta de outorgar ao Supremo Tribunal o poder de restringir os efeitos temporais da declaração e fazê-la meramente prospectiva (ou ex nunc) foi rejeitada na elaboração da Constituição de 1988, na revisão de 1993 e também na discussão da reforma judiciária da Emenda Constitucional n 45 . Claro, hoje há casos raríssimos de modulação dos efeitos temporais pelo Supremo Tribunal na ponderação de valores ou mesmo na interpretação da implementação da Constituição não como um ato completo com a promulgação, mas como um processo. Isso ocorreu, por exemplo, duas vezes, a propósito da Defensoria Pública, na falta de condições de efetivar em muitos Estados o modelo da Defensoria Pública desenhado na Constituição. Por isso, num habeas corpus, relatado pelo Ministro Sidney Sanches - esse é o primeiro exemplo -, considerou-se ainda constitucional o prazo em dobro dado à defensoria pública pelas suas precárias condiçōes de funcionamento em relação ao Ministério Público. Depois, em acórdão de que fui relator, considerou-se também ainda constitucional o artigo 68 do Código de Processo Penal, que legitima o Ministério Público para propor ações de indenizações de danos decorrentes de crime. O caso significativamente vinha de São Paulo, que só em 2006 organizou, nos moldes constitucionais, a sua Defensoria Pública. Então se entendeu que, naquele momento, seria mais grave declarar inconstitucional ou revogar aquele dispositivo, seria mais grave deixar desprotegidos interessados carentes, quando 
o que existia, a Procuradoria de Estado em funçōes de assistência judiciária, notoriamente não tinha condições de dar atendimento razoável a essa demanda.

No cancelamento da Súmula 394, que protrairia foro de prerrogativa de função, desde que o fato tivesse sido cometido no exercício da função para o tempo posterior à extinção do mandato do dignitário. No caso Mira Estrela, ${ }^{5}$ trata-se de um caso de uma ação civil pública em que se discutia o número de vereadores de determinada câmara municipal e em que o Supremo Tribunal entendeu de estabelecer uma verdadeira tabela proporcional do número de vereadores por faixas populacionais. Fui vencido, mas não interessa. O que quero chamar a atenção é: tomada essa decisão, no terceiro ou quarto ano do mandato, declarou-se inconstitucional a lei, mas com efeitos para o mandato seguinte.

No direito comparado, o problema da Áustria, que é a sede original do controle concentrado, há de ser posto de lado, porque é um sistema todo da concepção teória de Kelsen que nunca adotou a tese basilar do sistema americano da nulidade da lei inconstitucional, mas, sim, da anulabilidade da lei inconstitucional e, portanto, com efeitos ex nunc a partir da declaração da Corte Constitucional. É verdade que o sistema levou depois a um problema que se teve de transigir com o dogma kelseniano da anulabilidade. É que, como na mecânica do sistema europeu, numericamente mais que por ação direta, a questão condicional chega por argüição surgida num caso concreto, em que o juiz, considerando relevante, suspende o processo e remete à Corte Constitucional a argüição de inconstitucionalidade. Mas, levada às últimas conseqüências, como na redação primitiva da Constituição austríaca de 1920, aquele que provocara a questão de inconstitucionalidade ficaria a ver navios, porque a inconstitucionalidade só valeria posteriormente. Mas a verdade é que se assiste no mundo todo a uma progressiva admissão da chamada modulação de efeitos temporais, que os menos entusiasmados preferimos chamar de "manipulação dos efeitos temporais".

Na República alemã, por várias vezes chamada de "declaração de inconstitucionalidade sem pronúncia de nulidade", de que são exemplos aqueles a que me referia da Defensoria Pública, ou da imediata igualdade de gêneros da Constituição alemã, que, declarada a inconstitucionalidade da legislação existente, criaria um vácuo mais anti-isonômico do que declarar ainda constitucional, com apelo ao legislador, para que formulasse lei correspondente ao novo modelo constitucional.

Nos Estados Unidos mesmo - e aí se declarando que a questão nāo era de teoria, mas de pura política judiciária -, alguns casos célebres da Corte de Warren afirmam sobretudo garantias individuais em processos criminais, a partir do célebre caso Gideon ${ }^{6}$, em que se reconheceu ao acusado o direito à assistência técnica de advogado nos processos criminais. A Corte declarou explicitamente que isso, salvo naquele caso, não teria efeito quanto aos processos passados, dizendo claramente com o pragmatismo anglo-saxão que se tratava de uma medida de política judiciária.

5 RE 197.917/SP, rel. Min. Maurício Corrêa, DJ 7/5/2004.

6 Gideon v. Wainwright. 372 US 335 (1963). 
Na verdade, é preciso reconhecer que é crescente na doutrina comparada a denúncia dos inconvenientes da solução ortodoxa da nulidade da lei constitucional em todos os tempos. Teve grande repercussão na discussão brasileira um primoroso estudo de um notável constitucionalista espanhol, Eduardo García de Enterría, que tem, além de observaçōes teóricas sérias, uma observação quase de psicologia judiciária, com base na qual diz que a imposição em todo e qualquer caso da declaração de nulidade da lei, afetando a segurança jurídica, ou atos praticados de boa-fé, ou fatos consumados etc., levava, na verdade, os tribunais a engolir como constitucionais leis patentemente inconstitucionais com o fim de evitar o terremoto que surgiria da eficácia ex tunc.

O salto no Brasil vem com a lei, a chamada Lei da ADIn ( $n^{\circ} 9.868 / 98$ ), obra do Congresso Nacional, mas com profundas inspirações no meu querido colega Ministro Gilmar Mendes e na sua visāo expansiva do poder do Tribunal em tudo quanto diga respeito a controle de constitucionalidade. E aí se estabeleceu que, ao declarar a inconstitucionalidade de lei ou ato normativo, e tendo em vista razões de segurança jurídica ou de excepcional interesse social, poderá o Supremo Tribunal, por maioria de dois terços de seus membros, restringir os efeitos daquela declaração, ou decidir que ela só tem eficácia a partir do seu trânsito em julgado ou de outro momento que venha a ser fixado.

Diversos dispositivos desta lei são objeto de uma ação direta de inconstitucionalidade, de que sou relator, cujo julgamento ainda espero concluir exatamente sobre este artigo 27. As demais foram consideradas improcedentes, algumas sem maior consistência.

Uma interessante, que é o poder de, ao conceder a medida cautelar numa ação direta, determinar que não tenha aplicação a legislação anterior, que parte da experiência do Tribunal de que, muitas vezes, a lei anterior àquela que se declara inconstitucional era muito mais inconstitucional. Mas, afora essa, a inconstitucionalidade deste artigo 27 é o grande problema, sobre o qual há duas objeções fundamentais: primeiro, de inconstitucionalidade formal, por ter sido esta inovação suscitada posta em lei ordinária, até com argumento histórico de que por duas ou três vezes pelo menos o Congresso, desde a Assembléia Nacional Constituinte, recusou uma fórmula mais acanhada, que chegava apenas à declaração dos efeitos a partir da decisāo. E a de inconstitucionalidade material, que seria a incompatibilidade dessa modulação, pelo menos com a amplitude em que posta, com o sistema difuso e particularmente. Quer dizer, no sistema difuso, o reconhecimento de eventuais direitos adquiridos e atos jurídicos perfeitos que tenham como ponto de partida a inconstitucionalidade daquela lei. Mas, na pendência da ADIn, o Tribunal, como não se concedeu Medida Cautelar, tem aplicado o artigo 27 com extrema circunspecção, em casos em que eu diria, independentemente dela, o Tribunal já tinha feito algumas vezes.

Eu tenho muito temor. Não lhes posso anunciar nenhum juízo, porque eu mesmo não estou muito seguro, por isso mesmo se interrompeu o julgamento, 
mas eu tenho temor é do barateamento dessa modulação de efeitos temporais, sobretudo fundado em razões de Estado, fundado em dificuldades financeiras que essa ou aquela decisão constituir.

Eu ia falar-lhes que está em xeque o problema da suspensão de eficácia de norma pelo Senado, que, se dois votos ilustres, do ministro Eros Grau e do ministro Gilmar Mendes, consideram obsoleto, reservando o papel de dar publicidade à decisão do Supremo Tribunal. Entendem eles ter, por si, ainda que proclamada no controle difuso, a eficácia erga omnes e vinculante. Cuida-se de um caso notório da declaração de inconstitucionalidade pelo Tribunal, em um habeas corpus, da regra da lei dos crimes hediondos que impunha o regime fechado e integral aos condenados com base naquela lei, que o Tribunal, por seis a cinco, declarou inconstitucional. E o juiz do Acre não só indeferiu o primeiro requerimento, como pôs uma nota no lugar de costume no seu cartório dizendo que não a aplicará, porque é uma decisão que só se aplica ao fulano que era paciente no habeas corpus julgado pelo Tribunal e que ele continua considerando extremamente constitucional a lei e não aplicará o entendimento do STF. Não sei se, pelo tom desaforado da rebeldia, terá estimulado essa reação de que a suspensão da eficácia da norma pelo Senado se tornou obsoleta e houve uma verdadeira mutação constitucional. Adiantei meu voto em contrário, malgrado reconheça que, desde a introdução do conceito do controle concentrado, esta intervenção do Senado perdeu muito sua razão de ser. Já tivemos casos de declarar a inconstitucionalidade em um recurso extraordinário e ser necessário que na próxima semana se voltasse com uma ação direta sobre aquela mesma lei para que se lhe dessem efeitos erga omnes. Mas, de qualquer maneira, é uma tradicional competência expressa do órgão de um outro poder e eu não sei se é velhice, mas eu sei que me pareceu mais heterodoxo do que seria permitido dizer que essa função do Senado é de dar publicidade à decisão do Supremo Tribunal, ainda que no controle na decisão de processos subjetivos. $\mathrm{E}$, ademais, hoje para os assuntos realmente graves, os inconvenientes do retardamento da omissāo do Senado estão superados pela possibilidade de emissāo de súmula vinculante. 